\title{
The Reality of Education on Global Citizenship in Jordanian Schools
}

\author{
Mohammad Saleem AlZboon ${ }^{1}$, Sarra AbdelHalim AlSleibi ${ }^{2}$, Nisreen Abdalhafed Alofishat ${ }^{2} \&$ Alaa Ahmad \\ Harahsheh $^{3}$ \\ ${ }^{1}$ Prof. in Educational Foundations, Faculty of Educational Sciences, The University of Jordan, Amman, Jordan \\ ${ }^{2}$ Dr. in Educational Foundations, Ministry of Education, Jordan \\ ${ }^{3}$ Dr in Educational Administration, Faculty of Educational Sciences.Amman Arab University, Jordan \\ Correspondence: Mohammad Saleem AlZboon, Faculty of Educational Sciences, The University of Jordan, \\ Amman, Jordan. E-mail: m.alzboon@ju.edu.jo
}

Received: Sep. 29, 2018

doi:10.5539/mas.v12n12p128
Accepted: October 92018

Online Published: November 19, 2018

URL: https://doi.org/10.5539/mas.v12n12p128

\begin{abstract}
The study aimed at identifying the reality of education on international citizenship in Jordanian schools from the point of view of the secondary school teachers in Jordan and knowing that there are statistically significant differences at the level of $(\alpha=0.05)$ in the sample of the study due to gender, specialization and years of experience. The study consisted of (33) items divided into (3) areas (school administration, school curriculum and teacher), and the sample of the study consisted of (516) teachers and teachers of secondary school in Balqa Governorate. the tool.

The results showed that the reality of education on global citizenship in Jordanian schools from the point of view of teachers came to a medium degree of the tool as a whole, and where the order of areas as follows: teacher, school administration, school curriculum. The results also showed that there were significant differences in $(\alpha=$ 0.05 ) in the field of school administration due to the gender variable and for the benefit of males, and there were no statistically significant differences in the school curriculum, teacher and the tool as a whole due to gender variable. (1 to 5 years), and there were no statistically significant differences in the school curricula, school administration, and the whole instrument due to the difference in specialization. For the variable of experience of the recommendations in the light of the results reached by the need to rehabilitate and train teachers and school administrations on how to achieve education on global citizenship by subjecting them to multiple training programs before and during the service and the need to include values, knowledge and skills of education on global citizenship in the school curriculum more clearly and accurately. Which is based on critical thinking, problem solving, cooperative work and work through projects.
\end{abstract}

Keywords: Citizenship, global citizenship, education on global citizenship

\section{Introduction}

\subsection{Introduce the Problem}

Education is a purposing organized social processes, exclusive to mankind from all creatures exist in this world. The main goal of education has been to prepare a good citizen of an integrated personality in all fields; physical, mental, psychological, social, and spiritual one. Education is, therefore, a necessary process to confront life and its requirements and to organize the public behavior in order to live in a proper way among society.

The educational process aims at achieving social integration through turning human beings from biological beings into social beings. They are turned so through promoting interaction between them and the elements of the environment surrounding them. Based on the aforementioned, social interaction has become one of the pillars of the development and formation of the social characteristics of one's personality. In addition, social interaction is also considered a fundamental mean for learning and coping. It is also a fundamental tool for organizing societies and communities and passing their cultures from one generation to another (Odeh, AlZboon,2018).

Educational system is the main gate of the other social systems; it is the one meant with the development of human resources needed for all other economic, cultural and political systems to enable them play their roles in society. Thus, the educational system has such importance due to its care of human progress, and development of society, for what education present in favor of human core, his progress, creativity and developing his abilities that make 
him able to adjust with the variation and capable to deal with future problems. Hence, mankind should be affective, creative, open to the world, and armed with the critical spirit (AlZboun, AlJa'afreh, AlMowadyah, 2016).

In Jordan, the philosophy of education aims at building the kind of citizen that is believing, belonging, and filled with human virtues so that the individual becomes, at the end of education stages, a one that is capable to evaluate the humanity of mankind, and to be able to make positive values and attitudes towards himself and towards others. His democratic values should be represented in his individual and social behavior. He should also be cling to his rights of citizenship and hold their responsibilities accordingly and finally to be able to solve his life problems. (AlKhawaldeh, AlZyoudi, 2013).

Creating an individual who is cling to his rights of citizenship and achieving the international citizenship for individuals in society suggests the necessity of integration in roleplaying of the educational and social institutions. The role of these institutions is to endeavor to achieve education of citizenship, and to educate to reinforce partnership, and awareness of the rights and duties. Therefore, it requires the contribution of different institutions of social establishing in the process of building citizenship among society individuals which are: Family, religious institutions, information institutions, and educational institutions. (Alma'amary, 2014).

The most important role of educational institutions is to plant the values of citizenship, since education is such affective manner in building nations, people and societies. Education is a basic factor in crystalizing the national identity and in conserving the ethical and religious heritage. Education is the gate to progress and development. The job of education should not only be summed up in cramming student brain with the hugest possible information, especially in the current age of information blast, because education has an ethical, humanitarian and educational exceeds those limited intentions. That emphasizes the necessity to develop the critical thinking and accepting the other, the matter that confirms the need to activate the role of educational institutions to achieve that target. (Hilal, 2010).

The most important educational institution in achieving citizenship is school; its role goes beyond positive attitudes and patriotic values of individuals, to providing them with all knowledge and information, national, cultural and social concepts that are associated with the national institutions in society. That can be achieved through school management, teacher and school curriculum. (AlAnaqra, AlBawaneh, AlDamanhouri, 2008).

The increasing attention of international citizenship led to more attention to the universal dimension of raising individual to international citizenship. This results in some effects on policies, curriculum, teaching and education. The UNESCO concept of education for international citizenship includes three main conceptual dimensions which are: cognitive field, social-sentimental field, and behavioral field. (Jarrar, 2011).

The UNESCO has several achievements and conferences on international citizenship that raising on international citizenship or education for international citizenship, in all case they convey a close meaning to achieve the education of international citizenship. Education for international citizenship has been reinforced by the UNESCO since the Secretary General of the United Nations launched the international initiative of "Education first" in 2012, which made supporting the international citizenship one of its educational priorities. Mazero, 2015).

Education for international citizenship aims at teaching the learners how to study beliefs and values and their impact in the process of social and political decision making and the images about civil commitment and social justice. It also aims at developing the behavior of caring for others and respect of variety, and developing the values of equity and social justice and the skills needed for critical analysis of the issues, taking part and contribute in the international issues on local, national and international levels as responsible international citizens responding and looking forward, and committed. (Mazero, 2015).

There are many modern educational attitudes and ideas that should directly be reflected on school curriculum and teacher's training and qualification. The teacher needs a continuous career development, the matter that to not possible to be provided in the light of school work. Therefore, many programs are being prepared to increase teachers' performance, and to help them accept themselves and accept their students for a better education and learning. (Shweiter, 2004).

The teacher is the most important factor in the education- learning process; he has such affect in creating the personality of learners and guiding their behavior and adjusting their attitudes and convictions. Thus, teacher has a key role in developing the concept of citizenship with what he seizes of intellectual, cultural, cognitive fields and skills. Teacher has the cultural and intellectual powers such as decision making, critical thinking, problem solving, analysis, concluding, and feedback, so teacher therefore is more knowledge, science and reasonable. (Atturk, 2016).

The reflection of citizenship values in the behavior and awareness of teacher's personality is so affective in students' consciousness and practise for citizenship values, besides the methods and strategies of teaching he follows and 
his ability to manage relationships with students, so that he can plant in his students the values he is trying to achieve such as dialogue, discussion, respect of freedom of speech, and the mutual respect with school society individuals. (AlMarhaby, 2008).

It is important for the education of international citizenship that the school administration provides an ideal educational environment, based on a group of principles such as democracy, debate, cooperation, participation, experience and support. These all encourage, as an educational environment, in all educational phases on critical thinking, democratic debate and comprehensive vision. They also help making the educational environment interesting, positive, contemplating, and create kind of self-confidence, encourage understanding and mutual trust. Moreover they simulate students to learn from each others, which may give them a minor image of our world. (Cabizodo \& Others, 2008).

Any school curriculum aims at making student earn three main factors; knowledge, values and skills. By this curriculum students get to know the cognitive side of citizenship education, enlightening them with values of democracy, humanity, human rights and freedom, and focus on the skills of citizenship education such as communication, learning through thinking with its different categories and the sustainable development, and other skills. (AlBahry, 2015).

School is one of the most important educational institutions that should completely and perfectly be invested to plant the values of international citizenship, to guarantee the openness of the individual to the world which is now available for them at any place and at any time. In addition to the multiplication of technology means, the insurance of accepting cultural variety and deal with it in a critical spirit. International citizenship education is one of the basic educational pillar an individual needs in light technological progress our current age.

\subsection{Problem of the Study and Its Questions}

Recently, many countries witnessed turbulent successive events resulted in disassemble and diaspora of their individuals as if they never belonged to one homeland and live in same society. Many social changes took place, wars and trouble, which all led to make social change limited only in degradation and decline, on the contrary to what is supposed in societies of development, progress and prosperity. Accordingly, the attention to international citizenship increased as a means to unify societies intellectually, socially, psychologically, religiously, and scientifically.

There are many institutions that can contribute in developing international citizenship of the individual such as family, religious institutions, information institutions, and educational institutions. But school is still one of the important educational institutions, for its main role in developing the international citizenship, building the personality of an individual and strengthens his belonging to homeland, and providing him with information and skills required for international citizenship. Therefore, the problem of this study represented in answering the following questions.

1. What is the impact of education reality on international citizenship in Jordanian schools in perspective of high school teachers?

2. Are there differences of statistical significance at $(\alpha=0.05)$ in the estimations of the study sample in favor of gender, specialization, and years of experience variables?

\subsection{Objectives of the Study}

The study aimed at recognizing the reality of education on international citizenship in Jordanian schools in perspective of secondary stage teachers in Jordan. And to recognize the existence of differences of statistical significance at the level of significance $(\alpha=0.05)$, in estimations of the study sample related to variables of gender, specialization and years of experience.

\subsection{Terms and Procedural Definitions of the Study}

The study adopts the following terms and procedural definitions:

* Citizenship-Idiomatically: a situation guaranteed by law and customs whereby members of society have the right manage public affair equally and in freedom. (Asi, Taha, Nabha, Rahhal, 2010. P.11).

* Citizenship Procedurally: Citizenship is a description of individuals who live on a land of a society by which they get many rights being citizens in their society, and what they hold of responsibilities and duties towards this society, and acting with consciousness and responsibility towards their society and their homeland and towards others, and to act with the desired behavior socially, culturally, and intellectually.

* International Citizenship- Idiomatically: "the feeling of belonging to the wider society and common humanity. 
It strengthens the political, economic, social, and cultural coherence between local, national and international levels." (Mazero, 2015. P14).

* International Citizenship- Procedurally: the feeling of belonging to a wider society that exceeds the national borders, a feeling justifies the common denominator between mankind. This feeling is fed by the images of coherence between the local and the universal, the national and the international.

* Education for International Citizenship- Idiomatically:

It is the education that builds the knowledge, skills, values, and the behaviors needed by learners to be able to contribute in a more merging, just and peaceful world. (Mazero, 2015. P15).

- Education for International Citizenship- procedurally:

It is the education of learners from all age categories, and implanting values, information, and skills which are based on respect of human rights, social justice, variety, and environment sustainability, which is to be consolidated by school so that their school provide them with all they need to be responsible international citizens, besides granting them the chance to practise their rights and fulfill their obligations to build a better world and future gathers all.

\subsection{Limitations of the Study}

Objective Limitations: This study will search the impact of education on international citizenship in Jordanian schools from teachers' point of view.

Human limitations: This study will only include male and female teachers of secondary stage in Jordan.

Geographic Limitations: This study will take a sample of male and female teachers of secondary stages in AlBalqa Governorate.

Time Limitations: This study will be conducted during the second semester of the educational year 2016/2017.

\section{Previous Studies}

The following is a demonstration of the previous studies with relevance to the current study subject, and that are reached in order, according to their timeline, from oldest to newest:

(Moizumi, 2010) conducted a study aimed at recognizing the impact of educational practices on international citizenship in elementary schools of Ontario, Canada and British Columbia. The sample of the study consisted of two teachers of elementary stage, one of them teaches in Columbia and the other in Ontario. Throughout class notes, personal interviews, and document analysis, the study concluded several results: the possibility of teaching of international citizenship through critical thinking on international issues and events, and applying what students learn in the actual world. The study also concluded that cooperative work among teachers and students contributes in reinforcing their values of international citizenship, and all needed resources must be provided and prepare school administrations to achieve education for international citizenship and turn them into practices for teachers especially the newly working ones.

Both (Moon \& Koo, 2011) conducted a study aimed at examining the impact of including international citizenship educational fields in syllabus on traditional civil thoughts related to national identity, constitutional rights, and nation in South Korea. The researchers followed a multiple approach to analyze the books of civil education to recognize these changes. The results shown that civil thoughts were still basic elements in books, but with less attention towards it in contrast to the increasing attention to international citizenship topics. Also content and show were focusing more on student, where students are encouraged to be guided with a self-motivation, with the power to interact in international community.

Moreover, (Somani, 2011) conducted a study aimed at exploring the degree of impact of English syllabus and teachers' high demographic, and literature options for Muslim students on the way English language teachers teach international citizenship in public and Islamic school in Ontario. The study investigates three matters: how English teachers imagine education for citizenship by using the expectations of learning the enlightened, active and purposeful citizenship, in a way that supports their ethical options and practices the dimensions of civil education, and what degree does English teacher provide a comprehensive space for Islamic perspectives. The sample of the study consisted of (4) participants, two of each school subject. Through class notes, personal interviews, and document analysis, the study concluded a couple of results: the study shown that English language teachers succeeded in enriching purposeful citizenship, meanwhile the study pointed out to the necessity to have a clearer relationship in school syllabus and teachers' practices to plant the enlightened and active citizenship in English language. This study also indicated that the specific ethical choices for teachers besides educational teaching on 
citizenship, provides more comprehensive space for the breeded Islamic identities in English language.

Furthermore, (Kronfli, 2011) conducted a study aiming at comparing the effects of the used two syllabus in education for international citizenship, which were: the international educational experience and comprehensive school syllabus by using the "Round Square" as a case of study, where the international association for high schools gathers both ways to reinforce the international citizenship. The study searched the specifications of international citizenship for (185) graduates of "Canadian Round Square Schools", the results indicated that trying to achieve international citizenship inside schools not only a possible values, but also following a comprehensive approach on school level is an effective way to teach international citizenship as an international educational experience. These results are valuable because many schools have no resources, abilities, and motivation for international citizenship programs, especially if these programs depend on the activities of international education.

Also (AlSarhan, Abbabneh, Abu-Nair, 2015) conducted a study aimed at discovering the proposed model for international citizen in the perspective of educational leaders in Jordan. The society of study is leaders of education in Jordan which can be divided into two categories; the first is all academics in Educational Sciences Faculty at the University of Jordan, and the second all governmental school headmasters and educational supervisors in Amman. The study sample consisted of (162) of education leaders. The researcher used the descriptive analysis approach, and the questionnaire of study contained (42) paragraphs which validity and trustworthy was examined. The results shown that all dimensions of the tool gained a high degree of accordance. The descending order of the tool dimensions according to its averages was: the values of international citizen, the knowledge of international citizenship, and the skills of international citizen, which meant there is a significant accordance between leaders of education in Jordan on the importance of the tool item that describes the international citizen.

(Zaqawa, 2015) had also conducted a study aimed at recognizing the role of school in educating students on the values of citizenship in the perspective of preparatory education teachers, in the light of variables of gender, career experience, and the subject of teaching. In order to achieve that, the researcher designed a questionnaire consisted of (94) paragraph distributed on four fields: the role of teaching program, the role of teacher, the role of school atmospheres, and the role of school activities. A sample of (180) had been applied on male and female teachers from Ghleizan State in Algeria. This study uncovered that the level of school role was middle in developing the vales of citizenship. The field of teacher's role came in high level, while the other fields were ranked as follows: role of school atmospheres, role of teaching program, and role of school activities, all came in middle level. The results indicated that there were no differences of statistical significance related to the variables of gender, career experience, and subject of teaching.

(Alma'amary, 2015) conducted a study aimed at recognizing the degree of including social studies curriculum for the education fields related to international citizenship and teacher methods in teaching them in their perspective, and uncovering the variables of gender, teaching experience, specialization, and educational stage in perspective of sample individuals. In order to achieve goals of study, a questionnaire of (43) paragraph, distributed into two main categories. After making sure of the validity, trustworthy and stability of the tool, it had been applied to a sample of (291) working male and female teachers in governmental schools of Muscat Governorate. The study concluded several results: "the approach of social studies focuses on issues and problems of environment worldwide", "tolerance to others", "focusing on international economic issues", and the most used activities by individuals of the sample to teach subjects associated with international citizenship mentioned in social studies books are: encouraging students to express their opinion and respect others' opinion and urging them to follow up the media to know the international events". They use methods of teaching that are based on teachers as the way of teaching these subjects. The study discovered an effect to the variable of the educational stage of the sample individuals on the average of their perspectives about parts of education related to international citizenship which are under the focus of social studies approach while there is presence for the variables of gender, specialization, educational experience on the average of sample individuals' opinions about the impact of education for international citizenship in the Sultanate of Oman.

(AlAdwan, 2015) made a study aimed at establishing a training program for history teachers in the light of international citizenship principles, and examining its impact on the level of their cognition of these principles in Jordan. The sample of the study consisted of (26) male and female teachers, who had been selected randomly from teachers of history for the higher elementary stage in the Directorate of Education in Madaba. To achieve the goals of this study, a training program had been established, based on principles of international citizenship, which are: international peace, democracy, human rights, human and environment, scientific thinking, technology, and multicultural. A cognitive test on the principles of international citizenship had been prepared, and after making all statistical analyses, the study indicated that teacher's degree of prior cognition for the higher elementary level of international citizenship principles was less than educationally accepted level $(80 \%)$. The study shown the 
presence of differences of statistical significance at $(\alpha=0.01)$ between the levels of post cognition among history teachers for higher elementary stage of international citizenship principles and the educationally accepted level $(80 \%)$, for the training program in each field of international citizenship and for all fields together.

(Boutabbal, 2016) also conducted a study aimed at investigating the role of school through the syllabus of preparatory stage in developing and activating the values of citizenship and enroot them through individuals personality. The researcher adopted the approach of content analysis for both subject of Islamic and civil education for all educational years for the preparatory and secondary stages of education system in Algeria. The study concluded that school plays a role in making teacher earn the values of citizenship in all fields such as political and law, but it was noticed that there were a shortage of care towards behavioral and psychological sides of citizenship values.

In the light of reviewing previous studies, we had benefited from knowing Arab and foreign references which handled the topic of this study. This study has the advantage through its aim of recognizing the impact of education on international citizenship in Jordanian schools from high school teachers' perspective. This study agreed with the study of (Shdeifat, 2010) and (Zaqawa, 2015) on the using the questionnaire as a main tool to collect the data of the study, and been different from these studies for including the school administration and school syllabus.

\section{Methodology of the Study}

Descriptive method had been used for being the best for the study.

\subsection{Community of the Study}

Community of the study consisted of all males and female secondary school teachers in Balqa Governorate who are (1463) teachers according to the data provided by Ministry of Education: www.moe.gov.jo

\subsection{Sample of the Study}

The study sample was applied to (516) teachers and secondary school teachers in Balqa Governorate who were selected in a simple random methods.

\subsection{Validity of Study Tool}

To examine the validity of study tool, it had been distributed in its preliminary print onto (10) of arbitrators specialized in Education in Jordan Universities in order to have their opinions and commentary on the paragraphs of the study tool in terms of meaning obviousness, linguistic editing, and the degree of its suitability for the field of study, in addition to any modifications or additions they recommend, which will all be taken into consideration at the average of $(80 \%)$ of arbitrators perspectives.

\subsection{Stability of the Tool}

All three fields of tool stability had been examined by using Kronbach equation (Alfa) for interior consistency through applying the tool on (20) teachers of the study community and from outside the study community. Then the interior consistency had been examined by using Kronbach equation (Alfa). The stability coefficient for the three fields of the study tool reached at 0.958 together.

\section{Discussion of Study Results:}

Study results will be discussed as per its questions and as follows:

4.1 Discussing the results of the first question: What is the impact of education on international citizenship in Jordanian schools from the perspective of secondary school teachers in Jordan?

To answer the first question, all arithmetic averages, standard deviations, ranks, classifications for the impact of education on international citizenship from the perspective of secondary stage teachers in Jordan, as shown in table No. (1):

Table No. (1). arithmetic averages, standard deviations, rank, and order of the impact of education on international citizenship in Jordanian schools in the perspective of secondary stage teachers in Jordan.

\begin{tabular}{|c|c|c|c|c|c|}
\hline Rank & Number & Fields & $\begin{array}{l}\text { Arithmetic } \\
\text { Average }\end{array}$ & Standard Deviation & Mark \\
\hline 1 & 3 & Teacher & 3.87 & 0.716 & High \\
\hline 2 & 1 & School Administration & 3.46 & 0.901 & Middle \\
\hline
\end{tabular}




\begin{tabular}{lllll}
\hline 3 & School Syllabus & 3.43 & 0.838 & Middle \\
& Total & 3.58 & 0.674 & Middle \\
\hline
\end{tabular}

Table No. (1) Indicates that the impact of education on international citizenship in Jordanian schools in the perspective of secondary stage teachers in Jordan came in a middle place for the tool with an average reaches at (3.58), with a standard deviation reaches at (0.674). This can be explained relying on the fact that school did not opened enough to achieve education for international citizenship, since school is the most important educational institution that is responsible for planting the values of international citizenship. This result also interprets why school is still far from achieving the openness of the educated to the Arab world and the international thought, and the aware understanding for the facts, concepts, ties with cultural, geographic, and demographic environments locally and globally, in addition to be open to what is in human cultures which, in turn, are of the most important goals to the philosophy of education. This result emphasizes that achieving the goals of education regarding education for international citizenship remained on theoretical level and did not reach to the level of practice and application, which is represented on the ground with Jordanian schools. This result agreed with the study of (Zaqawa, 2015) and (Shdeifat, 2010), where schools role in developing the values of citizenship, belonging and homage came in middle mark as per the teachers opinion.

Meanwhile, on the hand of fields of study, the field of teacher came in the first place with a high arithmetic average reaches at (3.87), followed by the field of school administration in second place with an average reaches at (3.46), while school syllabus came in third and last place with an average reached at (3.43) in middle mark.

The first class mark result of the field of teacher with an average (3.87) in achieving education for international citizenship in Jordanian schools is associated with the fact that teacher is the core of education process, and is the active element in the educational process, he is in direct communication with students and school administration, and has an effective and positive impact on students, in addition to being in charge of turning school syllabus to be a practiced behavior by students. Teacher's mission is not only teaching students science and knowledge, but also to be himself an example for his students to be followed. (Moizumi, 2010)'s study referred to that teachers' degree of understanding and ability to teach students international citizenship reflects on the ability of education for international citizenship through critical thinking of universal issues and events, and that cooperative work between teachers and students helps in reinforcing the values of international citizenship for students. This result matches with the study of (Zaqawa, 2015) where teacher's role came in the first place with hi mark.

The result of school administration field can be returned to its rank in second place with average (3.46) in middle place, that can be explained in the light of limited relations between school administration and members of local and school society, the relation that should be built on strengthening pillars of education for international citizenship, and the achievement of partnership in decision making, justice, equality, cooperation and the team work. One of the reasons why the result of school administration came in second place is also the receding of international citizenship values on theoretical level away from practice and applying and ignoring the importance of activities' role in supporting the achievement of education for international citizenship.

In the meantime, the field of school syllabus came in the last place with the least average (3.43) and in middle mark, that's due to the deadlock of syllabus, where it needs abilities and skills of teacher to achieve the expected goals. There is also a weakness in the syllabus in performing some important values and skills such as critical thinking, problem solving, respect of difference, cultural diversity, and the responsibility towards rights, duties, and freedom. The study of (AlMa'amary, 2015) indicated that the approach of social studies concentrates on international environmental issues and problems, tolerance, and international economic issues. Thus, the values, skills, and information of education for international citizenship though included in the syllabus, but still receded in the approach of social studies such as national education and Islamic education. There is a general weakness in including these values and skills in all kinds of syllabus, in addition to the fact that they are not present in students' behavior unless they are present in teachers' behavior first. (Somani, 2011) study referred to the necessity of having a clearer connection in syllabus and teachers practices to plant the values of citizenship. This result matched the study of (Zaqawa, 2015), where the role of educational program was in middle place.

\section{Following is the detailed fields of study tool:}

Responses of sample individuals to the paragraphs of school administration field: 
Table No. (2). arithmetic averages, standard deviations, rank, and order of impact of education on international citizenship in Jordanian schools in the perspective of secondary school teachers in Jordan for the field of school administration

\begin{tabular}{|c|c|c|c|c|c|}
\hline Rank & Number & Statements & $\begin{array}{l}\text { arithmetic } \\
\text { Average }\end{array}$ & $\begin{array}{l}\text { Standard } \\
\text { Deviation }\end{array}$ & Mark \\
\hline 1 & 1 & $\begin{array}{l}\text { School administration plants the spirit of responsibility } \\
\text { among students as international citizens }\end{array}$ & 3.37 & 1.094 & high \\
\hline 2 & 2 & $\begin{array}{l}\text { School administration understands the disagreement with } \\
\text { others and gives them the chance to express themselves. }\end{array}$ & 3.65 & 1.052 & middle \\
\hline 3 & 13 & $\begin{array}{l}\text { School administration encourages students for } \\
\text { volunteering, initiatives, and different activities. }\end{array}$ & 3.63 & 1.117 & middle \\
\hline 4 & 3 & $\begin{array}{l}\text { School administration motivates teachers and students on } \\
\text { decision making. }\end{array}$ & 3.59 & 1.082 & middle \\
\hline 5 & 12 & $\begin{array}{l}\text { School administration develops the spirit of cooperation } \\
\text { between members of school society, parents and local } \\
\text { community }\end{array}$ & 3.58 & 1.099 & middle \\
\hline 6 & 4 & $\begin{array}{l}\text { School administration offers activities that help to } \\
\text { achieve the maximum degree of cultural diversity. }\end{array}$ & 3.56 & 1.081 & middle \\
\hline 7 & 11 & $\begin{array}{l}\text { School administration develops the spirit of cooperation } \\
\text { between teachers and students. }\end{array}$ & 3.51 & 1.089 & middle \\
\hline 8 & 5 & $\begin{array}{l}\text { School administration motivates teachers and students to } \\
\text { work harder for more just and fair world. }\end{array}$ & 3.49 & 1.126 & middle \\
\hline
\end{tabular}

Following: Table No. (2). arithmetic averages, standard deviations, rank, and order of impact of education on international citizenship in Jordanian schools in the perspective of secondary school teachers in Jordan for the field of school administration:

\begin{tabular}{|c|c|c|c|c|c|}
\hline Rank & Number & Statements & $\begin{array}{l}\text { Arithmetic } \\
\text { Average }\end{array}$ & $\begin{array}{l}\text { Standard } \\
\text { Deviation }\end{array}$ & Mark \\
\hline 9 & 9 & $\begin{array}{l}\text { School administration is committed to } \\
\text { "participation principle" through getting teachers } \\
\text { involved in decision making }\end{array}$ & 3.44 & 1.141 & middle \\
\hline 10 & 8 & $\begin{array}{l}\text { School administration caries out activities that } \\
\text { explain to the students' human rights and his } \\
\text { freedom. }\end{array}$ & 3.29 & 1.120 & middle \\
\hline 11 & 10 & $\begin{array}{l}\text { School administration is committed to } \\
\text { "participation principle" through getting students } \\
\text { involved in decision making }\end{array}$ & 3.25 & 1.126 & middle \\
\hline 12 & 6 & $\begin{array}{l}\text { School administration discuses local, regional, and } \\
\text { international issues with teachers }\end{array}$ & 3.22 & 1.217 & middle \\
\hline 13 & 7 & $\begin{array}{l}\text { School administration discuses local, regional, and } \\
\text { international issues with students }\end{array}$ & 3.09 & 1.250 & middle \\
\hline 14 & & Total & 3.46 & 0.901 & middle \\
\hline
\end{tabular}


Table No. (2) illustrates that the impact of education on international citizenship in Jordanian schools in secondary stage teachers' perspective came in middle mark and in high mark for the field of school administration, where arithmetic averages ranged between ( $3.09 \& 3.73)$ and standard deviations ranged between $(1.250 \& 1.094)$, where paragraph (1) which states (School administration plants the spirit of responsibility among students as international citizens) came in first place with the highest arithmetic average (3.73) with a high mark. This result matches with some results of (Moizumi, 2010) study on a point that preparing school administration helps to reinforce the values of international citizenship in students, besides the possibility for students to practice what they learnt in real world, and school administration should provide a suitable, educational, positive, contemplating and encouraging environment for students that can make them more confident, and encourage understanding, confidence between students and their teachers, motivating students to learn with others and accepting cultural diversity. Since that all helps school to represent a minor image of the world.

After that comes paragraph (2) which stated (School administration understands the disagreement with others and gives them the chance to express themselves), came in second place with arithmetic average of (3.65) in middle mark. This result is related to that the most important side of practicing education for international citizenship is that school administration should provide a decent educational environment based on a couple of principles such as democracy, dialogue, participation, cooperation, and experience. Also school is to provide care and support through carrying out different activities, as stated in paragraph (13) which states (School administration encourages students for volunteering, initiatives, and different activities) which came in third place with arithmetic average (3.36) and middle mark. There is weakness in school administrations about how to motivate teachers and students to decision making, that's what was stated in paragraph (3) which stated (School administration motivates teachers and students on decision making) with arithmetic average reaches at (3.59) in middle mark.

Then comes the paragraph of (School administration develops the spirit of cooperation between members of school society, parents and local community) with arithmetic average of (3.58) in middle mark. Teacher and students can achieve an efficient education for international citizenship only if they received the support and commitment of school headmasters, parents, and local community, in addition to providing school atmosphere, everlasting support, and enough resources. The achievement of this role depends on school administration. After that we have the paragraph of (School administration offers activities that help to achieve the maximum degree of cultural diversity) with arithmetic average of (3.56) in middle mark. Accordingly school administration is to try to provide a safe, comprehensive and attractive educational environment to reinforce the experiment of teaching and learning, and to support different types of education, allowing the participation of teachers of different backgrounds, in addition to school administration is reinforce cooperation and interaction between members of school society and correct interaction, respect, understanding cultural diversity, values, and other skills needed for living in a diversity world. That's what was mentioned in paragraph (11) which stated (School administration develops the spirit of cooperation between teachers and students) with arithmetic average of (3.51) in middle rank. Then comes the paragraph of (School administration motivates teachers and students to work harder for more just and fair world) with arithmetic average of (3.49) in middle mark. That explains the necessity of having justice presented in school administration behavior so that student might earn it. After that came the paragraph of (School administration is committed to "participation principle" through getting teachers involved in decision making) with arithmetic average of (3.44) in middle mark. Then we have the paragraph of (School administration is committed to "participation principle" through getting students involved in decision making) with arithmetic average of (3.25) in middle mark, where some school administrations make decisions on their own following some kind of dominance in spite of the participation of teachers and students in preparing plans and attending meetings but still the final decisions are made by the school administration. After that comes the paragraph of (School administration caries out activities that explain to the students' human rights and his freedom) with arithmetic average of (3.29) in middle mark. School administration's dependence on that such values should be taught by teachers through syllabus, and ignoring to activate its role in carrying out different activities to explain students' rights and freedom for them.

Then came the paragraph of (School administration discuses local, regional, and international issues with teachers) with arithmetic average of (3.22) in middle mark. After that comes the paragraph of (School administration discuses local, regional, and international issues with students) in the last place with the minimum arithmetic average of (3.09) in middle mark. This result can be referred to the weakness of school administration in mentioning issues out of traditional educational process, and also the weakness in managing dialogue and debates of such issues, besides the weakness in providing a safe space to discuss the controversial matters.

\section{Answers of sample individuals to paragraphs of school syllabus field:}

Table No. (3). Arithmetic averages and standard deviations rank and order for impact of education for international 
citizenship in Jordanian schools in the perspective of secondary stage teachers in Jordan for the field of school syllabus.

\begin{tabular}{|c|c|c|c|c|c|}
\hline Rank & Number & Statements & $\begin{array}{l}\text { Arithmetic } \\
\text { Average }\end{array}$ & $\begin{array}{l}\text { Standard } \\
\text { Deviation }\end{array}$ & Mark \\
\hline 1 & 19 & $\begin{array}{l}\text { School syllabus reinforces social values like } \\
\text { solidarity, tolerance, respect of others in students }\end{array}$ & 3.55 & 1.018 & middle \\
\hline 2 & 14 & $\begin{array}{l}\text { School syllabus develops students' awareness of } \\
\text { local, national and international issues. }\end{array}$ & 3.51 & 1.071 & middle \\
\hline 2 & 18 & $\begin{array}{l}\text { School syllabus plants humanitarian values in } \\
\text { students }\end{array}$ & 3.51 & 1.025 & middle \\
\hline 3 & 20 & $\begin{array}{l}\text { School syllabus reinforces the values of } \\
\text { cooperation and team work in students }\end{array}$ & 3.5 & 0.984 & middle \\
\hline 4 & 15 & $\begin{array}{l}\text { School syllabus reinforces the belonging to human } \\
\text { society, the common values and responsibilities } \\
\text { rely on human rights. }\end{array}$ & 3.48 & 0.984 & middle \\
\hline 5 & 17 & $\begin{array}{l}\text { School syllabus develops the values of respecting } \\
\text { the disagreement and cultural diversity in students. }\end{array}$ & 3.44 & 1.036 & middle \\
\hline 6 & 23 & $\begin{array}{l}\text { School syllabus makes students aware of their } \\
\text { rights, freedom and duties. }\end{array}$ & 3.4 & 1.059 & middle \\
\hline 7 & 16 & $\begin{array}{l}\text { School syllabus evolves the skills of critical } \\
\text { thinking for students. }\end{array}$ & 3.36 & 1.039 & middle \\
\hline 8 & 21 & $\begin{array}{l}\text { School syllabus develops the skills of problem } \\
\text { solving for students }\end{array}$ & 3.31 & 1000 & middle \\
\hline \multirow[t]{2}{*}{9} & 22 & $\begin{array}{l}\text { School syllabus develops students' sense of } \\
\text { responsibility. }\end{array}$ & 3.24 & 1.047 & middle \\
\hline & & Total & 3.43 & 0.838 & middle \\
\hline
\end{tabular}

Table No (3) illustrates that the reality of education on international citizenship in Jordanian schools in the perspective of secondary stage teachers came in middle mark for the field of school syllabus, where arithmetic averages ranged between (3.24 \& 3.55) and standard deviations ranged between (1.018 \& 1.047), as paragraph (19) which states (School syllabus reinforces social values like solidarity, tolerance, respect of others in students) came first with the highest arithmetic average (3.55) in middle mark. This result is referred to the presence of these values in specialized lessons in books of social studies such as national education and Islamic education, but we should guarantee the presence of such values in all specializations of school syllabus especially the scientific ones. Then in second place we have the two paragraphs (School syllabus develops students' awareness of local, national and international issues) and (School syllabus plants humanitarian values in students) with arithmetic average of (3.51) in middle mark. This result is referred to that in spite of the continuous evolvement of school syllabus to include local, national and international issues, but they should be supported with activities and education methods which are followed by teacher while handling the syllabus. Humanitarian values, social cooperation and belonging values all are supposed to be spontaneous in students, since human is a social creature by primitiveness, but the weakness of carrying out different activities that reinforce such values and the activation of the strategies of teaching such as strategy of cooperative work and learning through projects are all work to reinforce the planting of humanitarian values in syllabus. But syllabus requires a teacher who activates such activities and strategies to turn them on the ground into a behavior followed by students. Thus, these paragraphs came in middle marks as follows: paragraph of (School syllabus reinforces the values of cooperation and team work in students) came in third place with arithmetic average of (3.50) in middle mark. Then comes the paragraph of (School syllabus 
reinforces the belonging to human society, the common values and responsibilities rely on human rights) with arithmetic average (3.48) in middle rank. After that comes the paragraph of (School syllabus develops the values of respecting the disagreement and cultural diversity in students) with arithmetic average of (3.44) in middle mark. Then comes the paragraph of (School syllabus makes students aware of their rights, freedom and duties) with arithmetic average of (3.40) in middle mark. After that comes the paragraph of (School syllabus evolves the skills of critical thinking for students) with arithmetic average of (3.36) in middle mark. Followed by the paragraph of (School syllabus develops the skills of problem solving for students) with average of (3.31) in middle mark. After that came the paragraph of (School syllabus develops students' sense of responsibility) with average of (3.24) in middle mark.

The values and skills of 21 st century (accepting cultural diversity, sense of responsibility, critical thinking, and problem solving) which are of the most important values and skills to be gained to achieve education for international citizenship with the least arithmetic averages due to the need to teachers' role. Therefore, teacher plays a key role in achieving education on international citizenship with what he seizes of skills, culture, and information, where he can use a group of methods to activate these values, information and values and their presence in students' behavior and practice.

\section{Answers of sample individuals to the paragraphs of the field of teacher:}

Table No. (4). Arithmetic averages and standard deviations rank and order for reality of education on international citizenship in Jordanian schools in the perspective of secondary stage teachers in Jordan for the field of school teacher.

\begin{tabular}{|c|c|c|c|c|c|}
\hline Rank & Number & Statements & $\begin{array}{l}\text { Arithmetic } \\
\text { Average }\end{array}$ & $\begin{array}{l}\text { Standard } \\
\text { Deviation }\end{array}$ & Mark \\
\hline 1 & 24 & $\begin{array}{l}\text { Teacher respects students' personalities, } \\
\text { aspirations and their cultural content. }\end{array}$ & 4.01 & 0.856 & High \\
\hline 2 & 33 & $\begin{array}{l}\text { Teacher reinforces the values of tolerance between } \\
\text { students }\end{array}$ & 4.00 & 0.983 & High \\
\hline 3 & 32 & $\begin{array}{l}\text { Teacher achieves the principle of equality among } \\
\text { students }\end{array}$ & 3.96 & 0.929 & High \\
\hline 4 & 28 & $\begin{array}{l}\text { Teacher urges students on cooperative work and } \\
\text { the team work spirit }\end{array}$ & 3.92 & 0.895 & High \\
\hline 5 & 27 & $\begin{array}{l}\text { Teacher gives the chance to students for dialogue, } \\
\text { discussion and telling opinions }\end{array}$ & 3.88 & 0.875 & High \\
\hline 6 & 29 & $\begin{array}{l}\text { Teacher reinforces coexistence with others no } \\
\text { matter how different they are }\end{array}$ & 3.86 & .900 & High \\
\hline 7 & 25 & $\begin{array}{l}\text { Teacher activates different activities to achieve } \\
\text { students' participation }\end{array}$ & 3.83 & 0.832 & High \\
\hline 8 & 26 & $\begin{array}{l}\text { Teacher encourages students to invent, create and } \\
\text { come out with new things }\end{array}$ & 3.8 & 0.939 & High \\
\hline 9 & 30 & $\begin{array}{l}\text { Teacher trains students on the dialogue that is } \\
\text { based on proof and evidence }\end{array}$ & 3.71 & .958 & High \\
\hline \multirow[t]{2}{*}{10} & 31 & $\begin{array}{l}\text { Teacher follows teaching strategies rely on } \\
\text { problem solving and critical thinking }\end{array}$ & 3.7 & .989 & High \\
\hline & & Total & 3.87 & 0.716 & High \\
\hline
\end{tabular}


Table No. (4) Illustrates that reality of education on international citizenship in Jordanian schools in the perspective of secondary stage teachers in Jordan came in a high place for the field of teacher. The arithmetic averages ranged between $(3.70 \& 4.01)$ and standard deviations ranged between $(0.856 \& 0.989)$, where the paragraph of (Teacher respects students' personalities, aspirations and their cultural content) in first place with the highest arithmetic average of (4.01) in high mark. This result is referenced to that teacher is the most important factor in the teachinglearning process, where teacher has a key role in forming the personality of learner and guiding their behavior and adjusting his tendencies and attitudes. Teacher has therefore to take into account all social and cultural backgrounds, and to accept the cultural and thought diversity, to preach the values of tolerance, peace and democracy. Thus, the paragraph of (Teacher reinforces the values of tolerance between students) came in second place with average of (4.00) in high mark. Then comes the paragraph of (Teacher achieves the principle of equality among students) with average of (3.96) in high mark, that's due to teacher dealing with all students on the base of justice in all details of educational process, not only justice in evaluating students in examinations, but exceeding that to practicing justice in all levels. Achieving education for international citizenship on a group of education methods followed by teacher such as teaching based on cooperation, and teaching based on problem solving, and the teaching based on dialogue. in addition to encouraging students on invention and creativity.

Then come the paragraphs of (Teacher urges students on cooperative work and the team work spirit) with (3.92) in high mark. Then the paragraph of (Teacher gives the chance to students for dialogue, discussion and telling opinions) with an average of (3.88) in high mark. Then comes the paragraph of (Teacher reinforces coexistence with others no matter how different they are) with an average of (3.86) in high mark. After that comes the paragraph of (Teacher activates different activities to achieve students' participation) with an average of (3.83) in high mark. Then comes the paragraph of (Teacher encourages students to invent, create and come out with new things) with an average of (3.80) in high mark. Then comes the paragraph of (Teacher trains students on the dialogue that is based on proof and evidence) with an average of (3.71) in high mark. Then we have the paragraph of (Teacher follows teaching strategies rely on problem solving and critical thinking) with the least average of (3.70) in high mark. The skills of critical thinking, problem solving, and the dialogue based on scientific evidence came with the least arithmetic average due to the fact that such skills require that teacher should earn them and perfects them before applying them onto students.

4.2 Discussing the results related to second question: are there differences of statistical significance at $(\alpha=0.05)$ for the estimations of the study sample associated with the variable of gender, specialization and years of experience?

\subsubsection{Gender}

To answer this question, we have looked up arithmetic averages, standard deviations and test (T) for the independent samples on tool fields for the reality of education on international citizenship in Jordanian schools in perspective of secondary stage teachers in Jordan and the total mark of the tool is referred to gender variable as shown in table No. (5).

Table No. (5). Arithmetic averages, standard deviations and test (T) for the independent samples on tool fields for the reality of education on international citizenship in Jordanian schools in perspective of secondary stage teachers in Jordan and the total mark of the tool is referred to gender variable

\begin{tabular}{|c|c|c|c|c|c|c|c|}
\hline Field & Gender & Number & $\begin{array}{l}\text { Arithmetic } \\
\text { Average }\end{array}$ & $\begin{array}{l}\text { Standard } \\
\text { Deviation }\end{array}$ & "T" Value & $\begin{array}{l}\text { Freedom } \\
\text { marks }\end{array}$ & $\begin{array}{l}\text { Statistical } \\
\text { Significance }\end{array}$ \\
\hline \multirow{2}{*}{$\begin{array}{l}\text { School } \\
\text { Administration }\end{array}$} & Male & 312 & 3.56 & 0.828 & \multirow{2}{*}{3.093} & \multirow{2}{*}{514} & \multirow{2}{*}{0.002} \\
\hline & Female & 204 & 3.31 & 0.985 & & & \\
\hline \multirow{2}{*}{$\begin{array}{l}\text { School } \\
\text { Syllabus }\end{array}$} & Male & 312 & 3.48 & 0.832 & \multirow{2}{*}{1.545} & \multirow{2}{*}{514} & \multirow{2}{*}{0.123} \\
\hline & Female & 204 & 3.36 & 0.846 & & & \\
\hline \multirow{2}{*}{ Teacher } & Male & 312 & 3.83 & 0.672 & \multirow{2}{*}{-1.469} & \multirow{2}{*}{514} & \multirow{2}{*}{0.142} \\
\hline & Female & 204 & 3.92 & 0.777 & & & \\
\hline \multirow{2}{*}{ Total Mark } & Male & 312 & 3.62 & 0.641 & \multirow{2}{*}{1.727} & \multirow{2}{*}{514} & \multirow{2}{*}{0.085} \\
\hline & Female & 204 & 3.51 & 0.718 & & & \\
\hline
\end{tabular}


Table No. (5) Indicates that the value of (T) for the dimension of school administration reached (3.93) and it's a value if statistical significance at level 0.05 , which refers to the existence of differences in field of school administration for reality on education for international citizenship in Jordanian school is referred to gender variable. Differences were in favor of males with an average higher than that of females. Such result is referenced to that school administration in male schools is the main attraction of all activities, and it is the guiding and motivation for the work of teachers even more than teachers themselves. The point is that school administration in male schools is bolder in applying activities and events. In general, the culture of society gives more flexibility to males in carrying out activities, since some activities require working for late time to finish them, and this is not possible for females.

Table No. (5) Indicates that the value of (T) for the dimension of school syllabus and teacher. The total mark of the tool reached (1.545\&-1.469\& 1.728) consecutively. They are values that are of non-statistical significant at level 0.05 , which indicates to having no differences in the field of school syllabus and school teacher and the total mark of the tool is referenced to the variable of gender. Such result gets along with the study of (Zaqawa, 2015) in having no differences of statistical significance referenced to the variable of gender. Such result is returned to that teachers have the same point of view towards the subject, also the education on international citizenship is one of the most similar issues for both male and female teachers, as they have the same opinions over educating students on humanitarian values, tolerance values, solidarity and acceptance of cultural diversity. In addition to gaining the skills of critical thinking, problem solving, and others of values, skills and information that finally form the concept of education on international citizenship, besides to that school syllabus is everlasting material and in use for all Jordanian schools, and will be presented by teacher either a male of a female.

\subsubsection{Specialization}

To answer this question, we have looked up arithmetic averages, standard deviations and test (T) for the independent samples on tool fields for the reality of education on international citizenship in Jordanian schools in perspective of secondary stage teachers in Jordan and the total mark of the tool is referred to specialization variable as shown in table No. (6).

Table No. (6). Arithmetic averages, standard deviations and test (T) for the independent samples on tool fields for the reality of education on international citizenship in Jordanian schools in perspective of secondary stage teachers in Jordan and the total mark of the tool is referred to gender variable

\begin{tabular}{|c|c|c|c|c|c|c|c|}
\hline Field & Specialization & Number & $\begin{array}{l}\text { Arithmetic } \\
\text { Average }\end{array}$ & $\begin{array}{l}\text { Standard } \\
\text { Deviation }\end{array}$ & $\begin{array}{l}\text { "T" } \\
\text { Value }\end{array}$ & $\begin{array}{l}\text { Freedom } \\
\text { marks }\end{array}$ & $\begin{array}{l}\text { Statistical } \\
\text { Significance }\end{array}$ \\
\hline \multirow{2}{*}{$\begin{array}{l}\text { School } \\
\text { Administration }\end{array}$} & Scientific & 193 & 3.43 & 0.96 & \multirow{2}{*}{-0.635} & \multirow{2}{*}{514} & \multirow{2}{*}{0.526} \\
\hline & Humanitarian & 323 & 3.48 & 0.865 & & & \\
\hline \multirow{2}{*}{$\begin{array}{l}\text { School } \\
\text { Syllabus }\end{array}$} & Scientific & 193 & 3.4 & 0.892 & \multirow{2}{*}{-0.675} & \multirow{2}{*}{514} & \multirow{2}{*}{0.500} \\
\hline & Humanitarian & 323 & 3.45 & 0.805 & & & \\
\hline \multirow{2}{*}{ Teacher } & Scientific & 193 & 3.84 & 0.734 & \multirow{2}{*}{-0.635} & \multirow{2}{*}{514} & \multirow{2}{*}{0.525} \\
\hline & Humanitarian & 323 & 3.54 & 0.706 & & & \\
\hline \multirow{2}{*}{ Total Mark } & Scientific & 193 & 3.59 & 0.713 & \multirow{2}{*}{-0.793} & \multirow{2}{*}{514} & \multirow{2}{*}{0.428} \\
\hline & Humanitarian & 323 & 3.51 & 0.650 & & & \\
\hline
\end{tabular}

Table No. (6) Indicates that the value of (T) for the dimension of school administration, school syllabus and teacher. The total mark of the tool reached $(-0.635, \&-0.675, \&-635, \&-0.793)$ consecutively. They are values that are of non-statistical significant at level 0.05 , which indicates to having no differences in all fields (school administration, school syllabus and school teacher) and the total mark of the tool is referenced to the variable of specialization. Such result gets along with the fact that school administration stands at an equal distance between all specializations either scientific or humanitarian. The values of education on international citizenship are basically human values either included in social study books or scientific ones. Therefore, teacher is obliged to plant these 
values and carried them out on the ground to be represented practically and followed as a behavior among students. Skills and performances teacher has to own to be able to achieve education on international citizenship are not exclusive to a scientific or humanitarian specialization, but he has to own these skills in general regardless of his specialization in order to achieve education on international citizenship.

\subsubsection{Experience}

To answer this question, we have looked up arithmetic averages, standard deviations on fields of scaling the reality of education on international citizenship in Jordanian schools in perspective of secondary stage teachers in Jordan and the total mark of the tool is referred to experience variable as shown in table No. (7).

Table No. (7). Arithmetic averages, standard deviations of tool fields for the reality of education on international citizenship in Jordanian schools in perspective of secondary stage teachers in Jordan and the total mark of the tool is referred to experience variable

\begin{tabular}{|c|c|c|c|c|}
\hline Field & Experience & Number & $\begin{array}{l}\text { Arithmetic } \\
\text { Average }\end{array}$ & $\begin{array}{l}\text { Standard } \\
\text { Deviation }\end{array}$ \\
\hline \multirow{4}{*}{$\begin{array}{l}\text { School } \\
\text { Administration }\end{array}$} & from 1-5years & 137 & 3.55 & 0.854 \\
\hline & from 6-10 years & 210 & 3.42 & 0.894 \\
\hline & more than 10 years & 169 & 3.45 & 0.947 \\
\hline & Total & 516 & 3.46 & 0.901 \\
\hline \multirow{4}{*}{ School Syllabus } & from 1-5years & 137 & 3.54 & 0.821 \\
\hline & from $6-10$ years & 210 & 3.44 & 0.815 \\
\hline & more than 10 years & 169 & 3.33 & 0.875 \\
\hline & Total & 516 & 3.43 & 0.838 \\
\hline \multirow{4}{*}{ Teacher } & from 1-5years & 137 & 3.98 & 0.743 \\
\hline & from 6-10 years & 210 & 3.77 & 0.703 \\
\hline & more than 10 years & 169 & 3.89 & 0.698 \\
\hline & Total & 516 & 3.87 & 0.716 \\
\hline \multirow{4}{*}{ Total Mark } & from 1-5years & 137 & 3.68 & 0.652 \\
\hline & from 6-10 years & 210 & 3.53 & 0.661 \\
\hline & more than 10 years & 169 & 3.55 & 0.702 \\
\hline & Total & 516 & 3.58 & 0.674 \\
\hline
\end{tabular}

Table No. (7) Indicates the existence of virtual differences in arithmetic averages on the fields of the tool for the reality of education on international citizenship in Jordanian schools in the perspective of secondary stage teachers in Jordan and the total mark of the tool is referred to experience variable. In order to know the significance of these differences, we conducted the test of one-way analysis of variance (ANOVA). As shown in table No. (8).

Table No. (8). Results of one-way analysis of variance (ANOVA), to know the significance of differences on the fields of the tool for the reality of education on international citizenship in Jordanian schools in perspective of secondary stage teachers in Jordan and the total mark of the tool is referred to experience variable

\begin{tabular}{|c|c|c|c|c|c|c|}
\hline Field & Variance Source & $\begin{array}{l}\text { Total } \\
\text { Squares }\end{array}$ & $\begin{array}{l}\text { Freedom } \\
\text { marks }\end{array}$ & $\begin{array}{l}\text { Square } \\
\text { average }\end{array}$ & $\begin{array}{l}\text { "F" } \\
\text { Value }\end{array}$ & $\begin{array}{l}\text { Significance } \\
\text { level }\end{array}$ \\
\hline
\end{tabular}




\begin{tabular}{|c|c|c|c|c|c|c|}
\hline \multirow{3}{*}{$\begin{array}{l}\text { School } \\
\text { Administration }\end{array}$} & Between Groups & 1.375 & 2 & 0.688 & \multirow{3}{*}{0.847} & \multirow{3}{*}{0.429} \\
\hline & Inside Groups & 416.564 & 513 & 0.812 & & \\
\hline & Total & 417.94 & 515 & & & \\
\hline \multirow{3}{*}{ School Syllabus } & Between Groups & 3.064 & 2 & 1.532 & \multirow{3}{*}{2.190} & \multirow{3}{*}{0.113} \\
\hline & Inside Groups & 358.944 & 513 & 0.700 & & \\
\hline & Total & 362.008 & 515 & & & \\
\hline
\end{tabular}

Following: Table No. (8). Results of one-way analysis of variance (ANOVA), to know the significance of differences on the fields of the tool for the reality of education on international citizenship in Jordanian schools in perspective of secondary stage teachers in Jordan and the total mark of the tool is referred to experience variable

\begin{tabular}{|c|c|c|c|c|c|c|}
\hline Field & Variance Source & $\begin{array}{l}\text { Total } \\
\text { Squares }\end{array}$ & $\begin{array}{l}\text { Freedom } \\
\text { marks }\end{array}$ & $\begin{array}{l}\text { Square } \\
\text { average }\end{array}$ & $\begin{array}{l}\text { "F" } \\
\text { Value }\end{array}$ & $\begin{array}{l}\text { Significance } \\
\text { level }\end{array}$ \\
\hline \multirow{3}{*}{ Teacher } & Between Groups & 3.916 & 2 & 1.958 & \multirow{3}{*}{3.858} & \multirow{3}{*}{0.022} \\
\hline & Inside Groups & 260.313 & 513 & 0.507 & & \\
\hline & Total & 264.229 & 515 & & & \\
\hline \multirow{3}{*}{ Total Mark } & Between Groups & 1.902 & 2 & 0.951 & \multirow{3}{*}{2.102} & \multirow{3}{*}{0.123} \\
\hline & Inside Groups & 232.047 & 513 & 0.452 & & \\
\hline & Total & 233.948 & 515 & & & \\
\hline
\end{tabular}

Table No. (8) Shown that the value of "F" reached at (3.858), which is a value of statistical significance at the level significance 0.05 , and this points to the existence of differences in the field of teacher of reality of education on international citizenship in Jordanian schools, and such differences are referenced to the variable of experience. In order to know the significance of differences, we have conducted the Scheffe' Test of Post Hoc Comparisons for the field of teacher as per experience. The following table shows these results:

Table No. (9). Scheffe' Test of Post Hoc Comparisons for the field of teacher from reality of education on international citizenship referenced to the variable of experience

\begin{tabular}{llll}
\hline Field & Experience & $6-10$ years & More than 10 years \\
\hline \multirow{2}{*}{ Teacher } & $1-5$ years & $0.21420^{*}$ & 0.09828 \\
\cline { 2 - 4 } & $6-10$ years & & -0.11591 \\
\hline
\end{tabular}

Table No. (9) Indicates the presence of difference of statistical significance in the field of teacher for the reality of education on international citizenship, referenced to the variable of experience (1- 5 years) and between the experiences (6- 10 years). The differences were in favor of experience (1-5 years) and there were no difference in experience for the rest of years of experience. This result differs with (Zaqawa, 2015) study for not having differences of statistical significant referenced to the variable of experience. This result is associated with to the impact of training courses granted by the Ministry of Education for the new teachers, where trainers subject to urgent follow up for the period of (160) training hours when they start working for the Ministry of education. Besides passing an exam after this course, in addition to continuous follow up by the department of educational supervision and the scheduled field vistis to these teachers. Furthermore, new teachers are enrolling in these course hoping to learn new things and make progress in their career. New teacher have no limited date to finally sign their contracts with the ministry unless they spend three years of work along with the report that proves their career evaluation, which the annual report of teacher performance.

Table No. (8) shows that the value of "F" for the fields of school administration, school syllabus, and the total 
mark of the tool reached at $(0.847 \& 2.190, \& 2.102)$ consecutively, and they are a non-statistically significant values at the level of 0.05 , which proves the existence of not having differences in both fields; school syllabus and school administration, and the total mark of the tool is referenced to the variable of experience. This result agrees with the study of (Zaqawa, 2015) on having no differences of statistical significance referenced to career experience. Such result is referenced to that experience has no impact on teachers' point of view, and this means the relation of school administration cannot be specified by the years of experience of this administration's teachers, but the decisions are made, carried out, and activities as well in school atmosphere in general. As for school syllabus, the result is referenced to that the syllabus is a permanent subject and followed in all Jordanian schools, and will be taught by all teachers regardless of their years of experience, and that teacher is obliged to activate it in the educational process since his first day of work.

\section{Recommendations of the Study}

In the light of the results indicated by this study, we put forward the following recommendations:

Encouraging school administration to discus and solve local society problem in cooperation with students to get them involved in issues of their community, and try to create atmospheres based on principle of democracy and participation in decision making.

Participating of teachers in school administration and in decision making, which will positively reflect on the school atmosphere in general and on students in particular.

Qualifying and training teacher and school administrations on how to achieve education based on international citizenship through subjecting to training courses before and during work.

Making teachers aware by using teaching methods which are based on critical thinking, problem solving, cooperative work, and working through projects.

Including the values, skills and information of education for international citizenship in school syllabus, and be represented in teachers' and school administration's behavior.

\section{References}

Al Sarhan, K., Abbabneh, S., \& Abu- Nair. N. (2015). A Suggested Model for the Global Citizen from the Viewpoint of Educational Leaders in Jordan. European Journal of Social Sciences, 47(2), 26-247.

AlAdwan, Z. (2015). The impact of training course in developing the principles of international citizenship for history teachers in Jordan. Studies. Educational Sciences- Jordan, 42(1), 127-138.

AlBahry, M. (2015). The Educational Approach, Basis and Analysis (Vol. II). Amman, Dar Al Safa' Publishers and Distributors.

Alicia Cabezudo Christos Christidis Miguel Carvalho da Silva Valentina Demetriadou-Saltet Franz Halbartschlager Georgeta-Paula Mihai (2008). Global Education guidelines for global citizenship. Translated by (Afaf Mubarak and Tareq Mahdhawy). Lisbon: North-South Centre (NSC) of the Council of Europe.

AlKhawaldeh, T., \& AlZyoudi, M. (2013). Jordanian Educational System in the Third Millennium, Amman: Dar AlHamid Publishers and Distributors.

AlMamary, S. (2014). Education for citizenship in States of Gulf Council in the Arab Gulf countries: reality and challenges. Journal of Strategic Visions, 2(7), 38-61.

AlMamary, S. (2015). the degree of including the approach of social studies for sides of learning that are associated with global citizenship, and teacher methods in teaching it in their perspective. Journal of Arab Island and gulf studies (Kuwait), 41(156), 169-210.

AlMarhaby, Y. (2008). Factors affecting the values of citizenship for students of secondary stage in Emran Governorate. Unpublished Master Thesis, Sana'a University, Sana'a. Yemeni Republic.

AlZboon, M., AlJa'afreh, A., \& AlMawadya, R. (2016). System of Education and Learning in Jordan. Amman: Dar Wael Publishers and Distributors.

Asi, B., Taha, G., Nabha, K., \& Rahhal, H. (2010). State and Citizenship-Approaches and Directions, Beirut: Islamic Cultural Society for Information.

Atturk, S. (2016). Teachers role in reinforcing principles of homage and belonging. Teacher's Message- Jordan, $53(1), 40-42$.

BoTabbal, S. (2016). School role in developing values of citizenship for teachers: A pattern: Preparatory and secondary stage education. Journal of Human and Social Sciences, (23), 91-103. 
Hilal, A. (2010). A Seminar on Education and citizenship. Magazine of Modern Education League, 3(7), 409-413.

Jarrar, A. (2011). International Citizenship, Amman: Dar Wael Publishers and Distributor.

Kronfli, M (2011). Educating For Global Citizenship: An Exploration of Two Curricular Methods. University of Toronto.Retrieved at 5- May -2018 (5:10 pm) from: https://tspace.library.utoronto.ca/handle/1807/29476

Mazior, O. (2015). Global Citizenship Education: Educational Topics and Subjects. Beirut, UNESCO.

Moizum, E. (2010). Examining Two Elementary-Intermediate Teachers' Understandings and Pedagogical Practices About Global Citizenship Education, University of Toronto.Retrieved at 5- May -2017 (5:00 pm) from: https://tspace.library.utoronto.ca/handle/1807/24608

Moon, R., \& Koo, J. (2011). Global Citizenship and Human Rights: A Longitudinal Analysis of Social Studies and Ethics Textbooks in the Republic of Korea .Comparative Education Review, 55(4), 599-574.

Odeh, T., \& AlZboon, M. (2018). The Extent of Practicing Social Interaction Skills by Jordanian Elementary School Students in accordance with Carl Orff's Approach to Music Education. Modern Applied Scince, 12(3), 95-104.

Shdeifat, B. (2010). School role in developing the values of homage and loyalty for homeland to students of secondary stage in first Irbid educational directorate. Irbid for Studies and researches (Educational Sciences)Jordan, 13(2), 235-279.

Shwaiter, I. (2004). developing a training program based on educational efficiency to prepare social studies teachers for secondary stage in Jordan, and its impact in their practice for these efficiencies. Unpublished doctoral Thesis, Amman Arab University. Amman, Jordan.

Somani, R (2011). Educating for Citizenship in the English Secondary Classroom: A Case Study of Teacher Perspectives and Practice in Public and Islamic Schools in Ontario, University of Toronto.Retrieved at 5May -2018 (5:20 pm) from https://tspace.library.utoronto.ca/handle/1807/30108

Zaqawa, A. (2015). Teacher's role in developing citizenship values in perspective of preparatory education teachers. Journal of American Arab Academy of Science and Technology (AMARABAC), 6(17), 51-68.

\section{Copyrights}

Copyright for this article is retained by the author(s), with first publication rights granted to the journal.

This is an open-access article distributed under the terms and conditions of the Creative Commons Attribution license (http://creativecommons.org/licenses/by/4.0/). 